\title{
An Accurate Method for Estimating Sizes of Small and Large Plasmids and DNA Fragments by Gel Electrophoresis
}

\author{
By P. A. ROCHELlE, J. C. FRY,* M. J. DAY AND M. J. BALE \\ Department of Applied Biology, University of Wales Institute of Science and Technology, \\ PO Box 13, Cardiff CFI $3 X F, U K$
}

(Received 3 June 1985; revised 5 September 1985)

\begin{abstract}
Several regression methods were tested for estimating the sizes of a wide range of plasmids $(1 \cdot 37-312 \mathrm{MDa})$ and restriction fragments $(2 \cdot 2-14 \cdot 2 \mathrm{MDa})$ by agarose gel electrophoresis. The most accurate and least variable method was the multiple regression of $\log _{10}$ molecular size against $\log _{10}$ relative mobility and the reciprocal square root of the relative mobility. This method gave a good fit to all the data with low percentage errors of the molecular size estimates $(\leq 3.0 \pm 1.5 \%)$. It is suggested that with this method the molecular size of unknown plasmids can be accurately estimated using the plasmids from Escherichia coli V517 and E. coli IR713 as standards.
\end{abstract}

\section{INTRODUCTION}

For many years molecular sizes of plasmids and other pieces of DNA have been estimated by their mobility in electrophoresis gels. Aaij \& Borst (1972) showed a linear relationship between the logarithm of molecular size and mobility that could be used to estimate unknown sizes of bacteriophage and mitochondrial DNA up to $10 \mathrm{MDa}$. This approach was extended for plasmids of up to $95 \mathrm{MDa}$ by using a $\log / \log$ plot of molecular size and mobility (Meyers et al., 1976). Other workers have consistently been unable to accurately estimate molecular sizes of large plasmids with this method (Willshaw et al., 1979) because the $\log / \log$ plot is intrinsically curved. More complex approaches have been developed using mobility data obtained from restriction fragments of DNA to obtain linear relationships (Southern, 1979; Schaffer \& Sederoff, 1981), but these have rarely been used subsequently. Most currently accepted methods for measuring the molecular sizes of plasmids, such as by electron microscopy (Grindley et al., 1973) and from restriction endonuclease digests (Grinter \& Barth, 1976), are much more difficult and time consuming than direct gel electrophoresis. Consequently there is a need for a better method of estimating molecular sizes of DNA from their electrophoretic mobilities, particularly for the larger plasmids. The aim of this work was to develop such a method that would be easy to use routinely.

\section{METHODS}

Bacterial plasmids and cultural conditions. Molecular sizes of the plasmids used have all been estimated independently, by methods other than straightforward electrophoresis. In the following list of the plasmids used the reference quoted refers to the molecular size estimation. The plasmids, which were mainly in Escherichia coli and Pseudomonas spp., were pVA517A-H (Macrina et al., 1978), R300B (Grinter \& Barth, 1976), pGSS15, pGSS6 (Barth et al., 1981), pRPl (Lanka \& Barth, 1981), RP4 (Currier \& Morgan, 1981), R1drd19 (Jacoby et al., 1983), pWW0 (Lehrbach et al., 1983), TP1 16 (Grindley et al., 1973), R91, CAM (Jacob et al., 1977), RIP64 (Korfhagen et al., 1978) and pMGI (Hansen \& Olsen, 1978). All cultures were started from single colonies and streaked onto nutrient agar (Oxoid; CM3) plates which were incubated at $30^{\circ} \mathrm{C}$ for $18 \mathrm{~h}$. The larger single colonies were then used for the plasmid preparations. All strains were maintained on drug-free nutrient agar without plasmid loss.

DNA procedures. Plasmid DNA was isolated as described by Kado \& Liu (1981) for single colonies; following phenol/chloroform extraction the aqueous layer was removed using a wide bore $(2.5 \mathrm{~mm}$ inside diameter $)$ 
disposable $200 \mu \mathrm{l}$ tip. Using such a tip avoids shearing large plasmids and minimizes disturbance of the interface between the organic and aqueous phases. The restriction endonuclease EcoRI and bacteriophage $\lambda$ DNA were obtained from Sigma. $\lambda$ DNA was digested as recommended by the supplier.

Gel electrophoresis. Plasmid DNA $(50 \mu \mathrm{l})$ was mixed with $5 \mu \mathrm{l}$ of loading dye $(50 \%$, w/v, glycerol; $0.05 \mathrm{M}-\mathrm{T}$ ris buffer; $0.25 \%, \mathrm{w} / \mathrm{v}$, bromocresol purple; $\mathrm{pH} 7.9)$, and $25 \mu \mathrm{l}$ of this mixture was loaded into the wells of a $0.8 \%(\mathrm{w} / \mathrm{v})$ agarose gel (BDH; product no. 44302); in one experiment a $1.4 \%(\mathrm{w} / \mathrm{v})$ agarose gel was used. The gel was made up and run in Tris/borate buffer (pH 8.0; Tris, $10.8 \mathrm{~g}$; EDTA, $0.93 \mathrm{~g}$; boric acid, $5.5 \mathrm{~g}$; distilled water, 1 litre). Gels were run at $6 \mathrm{~V} \mathrm{~cm}^{-1}$ for $10 \mathrm{~min}$ followed by $12 \mathrm{~V} \mathrm{~cm}^{-1}$ for a further $2 \mathrm{~h}$. In one experiment the gel was run at twice this voltage gradient and in another experiment at $8 \mathrm{~V} \mathrm{~cm}^{-1}$. DNA was stained for $1 \mathrm{~h}$ in ethidium bromide $\left(0 \cdot 4 \mu \mathrm{g} \mathrm{ml}^{-1}\right)$ and washed in running tap water for $20 \mathrm{~min}$.

Gel examination. Gels were illuminated with an ultraviolet transilluminator (Ultraviolet Products, San Gabriel, Calfornia, USA) and photographed (Burton et al., 1982). Negatives were scanned with a Chromoscan 200 (Joyce Loebl, Gateshead, UK) to determine the position of the peak absorbance of each covalently closed circular plasmid or DNA restriction fragment band. Migration distance was measured from the front of each well to the absorbance peaks. Relative mobilities for plasmids and DNA fragments were calculated from the migration distance, as a percentage of the distance moved by the smallest plasmid in E. coli V517.

Statistical analysis. Regression analysis was done with Minitab (Ryan et al., 1976) using appropriate transformations $\left(x, x^{1 / 2}, \log _{10} x, 1 / x\right.$, and $\left.1 / x^{1 / 2}\right)$ of the molecular sizes and relative mobilities of the plasmids. These transformations were chosen because they hatve been recommended for use when curved regression lines need to be straightened (Velleman \& Hoaglin, 1981). A separate regression analysis was done for all the plasmids on each gel and the squared correlation coefficient $\left(R^{2}\right)$ and Durbin-Watson statistic noted (Chatterjee \& Price, 1977). The percentage errors of the predicted values for the plasmid molecular sizes were calculated from the residuals (predicted value - actual value) as a percentage of the actual molecular sizes. A multiple regression analysis was also done; the regression equation was

$$
\log _{10} M_{\mathrm{r}}=a+b_{1}\left(\log _{10} r\right)+b_{2}\left(1 / r^{1 / 2}\right)
$$

where $M_{\mathrm{r}}$ is the estimated molecular size, $r$ is the relative mobility and $a, b_{1}$ and $b_{2}$ are regression coefficients. The method of Southern (1979) used a modified relative mobility $\left(r^{\prime}\right)$ :

$$
r^{\prime}:=M-M_{0}
$$

where $M$ is the distance moved (mm) by the DNA band and $M_{0}$ is an empirical correction factor which helps fit a linear regression line (Southern, 1979).

\section{RESULTS AND DISCUSSION}

Eighteen independent gel electrophoresis experiments were done to determine the relative mobility of a wide size rar of plasmids (1-37-312 MDa). Regression analysis of these data was done to find a method which could be used to estimate sizes of unknown plasmids within this size range. As anticipated the regression of $\log _{10}$ molecular size against $\log _{10}$ relative mobility (LL) gave a reasonable fit for the smaller plasmids but grossly underestimated the sizes of the largest plasmids (Fig. $1 a, b$; Table 1 ).

To find a better pair of transformations. regressions were done on all the data with twelve combinations of different transformations. The efficiency of transformations in providing a good fit to a set of data can be assessed by the squared correlation coefficient $\left(R^{2}\right)$ and the Durbin-Watson statistic, both of which were calculated during the regression analysis (Chatterjee \& Price, 1977). The $R^{2}$ value gives the proportion of the variance in the data explained by the linear relationship between the regression variables. Thus for an $R^{2}$ value of $100 \%$ all the points would lie exactly on the straight line calculated by the regression, so the higher the value of $R^{2}$ the closer the data points are to a straight line. The Durbin-Watson statistic tests for autocorrelation in the residuals; this is only a meaningful test when the data points are ordered, and in this work the data were always ordered by molecular size. DurbinWatson tables are unusual in that two table values are given. A Durbin-Watson statistic lower than the lowest table value indicates significant autocorrelation; a value higher than the highest table value shows that no significant autocorrelation exists and the result for intermediate values is uncertain. For a bivariant regression analysis with eighteen data points, which was the maximum used here, the table values of the Durbin-Watson statistic were 1.151 and 1.391 . Significant autocorrelation between residuals indicates either curvature or a poorly fitting 

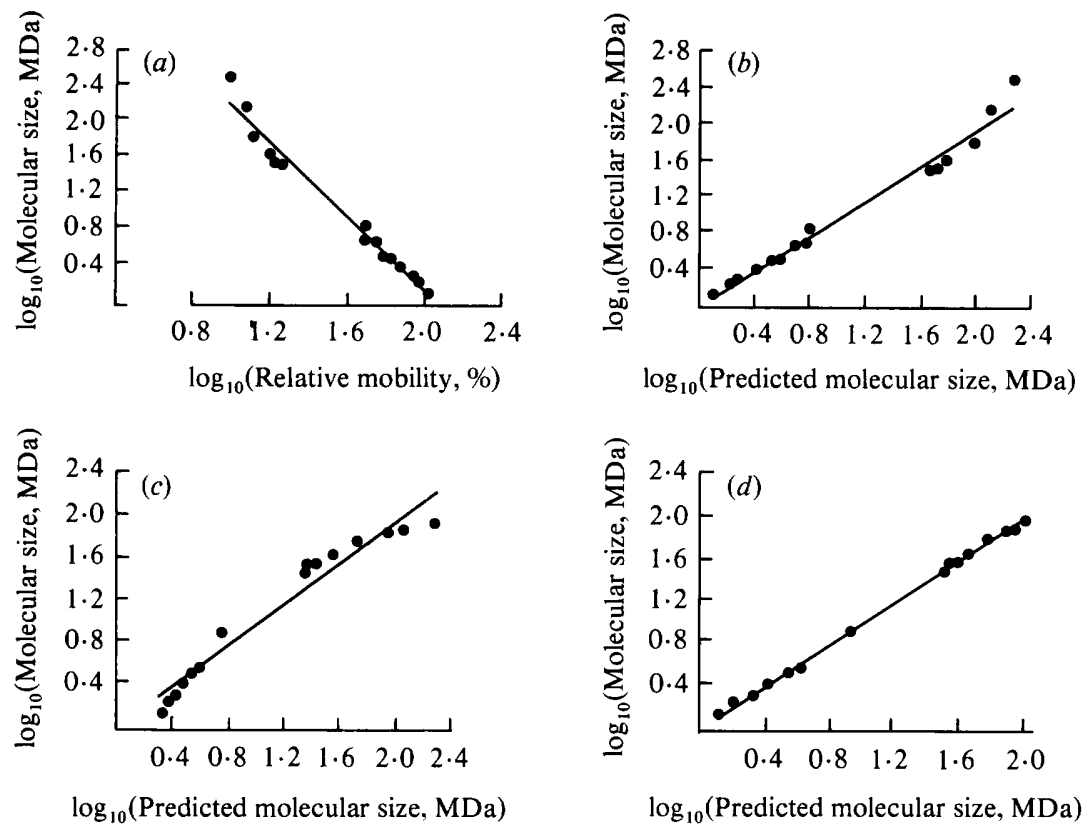

Fig. 1. Typical plots of $\log _{10}$ plasmid molecular sizes against $\log _{10}$ relative plasmid mobility $(a)$ and $\log _{10}$ predicted molecular sizes $(b-d)$. $\log _{10}$ molecular size was predicted by regression of $\log _{10}$ molecular size with $\log _{10}$ relative plasmid mobility $(b)$, reciprocal square root of relative plasmid mobility $(c)$ and both of these variables using multiple regression $(d)$. Regression lines are drawn which, for plots $(b)-(d)$, are also the lines of equality.

straight line; thus the higher the Durbin-Watson statistic the better the regression model fits the data. Using these criteria the most satisfactory transformations were the pair used in LL and $\log _{10}$ molecular size against the reciprocal square root $\left(1 / x^{1 / 2}\right)$ of the relative mobility regression (LR). For LR the $R^{2}$ value and the Durbin-Watson statistic were almost as high as for LL (Table 1).

In the plots of molecular size and predicted molecular size for both LL and LR methods (Fig. $1 b, c)$ the points did not lie on a straight line. As the curvatures of the points were in opposite directions multiple regression of $\log _{10}$ molecular size against $\log _{10}$ relative mobility and reciprocal square root of relative mobility (MR) should give a better fit to the data. This was clearly true for the typical results presented (Fig. 1d). Under the electrophoresis conditions tested there was a very good linear relationship between the predicted and real values for the molecular sizes of the plasmids used (1.37-312 MDa). Also MR consistently showed a higher $R^{2}$ value and Durbin-Watson statistic than LL or LR. MR on all eighteen sets of data showed much lower percentage errors for the plasmid molecular sizes (Table 1). The mean percentage error for all the molecular sizes of the plasmids examined was very much lower and less variable for MR than for the LL or LR methods. The mean percentage error for the smallest plasmid used $(1.37 \mathrm{MDa})$ was much larger than the rest $(11.6 \%$; Table 1$)$; consequently the mean percentage error of plasmids between 1.76 and $312 \mathrm{MDa}$ was only $2.53 \pm 1.06 \%$.

The multiple regression equation

$$
\log _{10} M_{\mathrm{r}}=a+b_{1}\left(\log _{10} r\right)+b_{2}\left(1 / r^{1 / 2}\right)
$$

can easily be used because programs and packages are readily available which can do multiple regression on all types of computer, and present no computational difficulties for calculating the regression coefficients. 
Table 1. Comparison of four regression methods for calculating mean errors of predicted molecular sizes of plasmids covering a wide size range

\begin{tabular}{|c|c|c|c|c|c|c|}
\hline \multirow[b]{2}{*}{ Plasmid } & \multirow{2}{*}{$\begin{array}{l}\text { Molecular } \\
\text { size } \\
(\mathrm{MDa})\end{array}$} & \multirow[b]{2}{*}{$n^{*}$} & \multicolumn{4}{|c|}{$\begin{array}{c}\text { Mean } \dagger \text { error }(\%) \text { from } n \text { values of predicted } \\
\text { molecular sizes obtained with the } \\
\text { following regression methods } \ddagger\end{array}$} \\
\hline & & & $\mathbf{L L}$ & LR & MR & S \\
\hline pVA517H & $1 \cdot 37$ & 11 & -3.8 & $+23 \cdot 8$ & $+11 \cdot 6$ & +62.9 \\
\hline pVA517G & $1 \cdot 76$ & 14 & $-5 \cdot 5$ & $+11 \cdot 1$ & $+2 \cdot 2$ & +87.9 \\
\hline pVA517F & $2 \cdot 02$ & 14 & -6.6 & $+4 \cdot 2$ & $-2 \cdot 4$ & +77.9 \\
\hline pVA517E & $2 \cdot 67$ & 14 & $-4 \cdot 3$ & $-3 \cdot 8$ & $-4 \cdot 1$ & $+61 \cdot 8$ \\
\hline pVA517D & $3 \cdot 38$ & 14 & $+1 \cdot 3$ & -6.5 & $-2 \cdot 3$ & $+54 \cdot 1$ \\
\hline pVA517C & 3.64 & 13 & $+11 \cdot 5$ & $-1 \cdot 4$ & $+0 \cdot 16$ & $+56 \cdot 2$ \\
\hline pVA517B & 4.81 & 14 & +19.8 & -0.8 & +3.5 & $+50 \cdot 2$ \\
\hline pGSS 15 & $7 \cdot 35$ & 6 & $-11 \cdot 1$ & $-12 \cdot 1$ & $-5 \cdot 1$ & -0.4 \\
\hline pGSS6 & $8 \cdot 19$ & 5 & $+18 \cdot 2$ & $+15 \cdot 1$ & $+5 \cdot 7$ & $+32 \cdot 7$ \\
\hline pVA517A & $35 \cdot 8$ & 15 & $+2 \cdot 3$ & $-3 \cdot 7$ & +0.08 & $-9 \cdot 7$ \\
\hline RP4 & $36 \cdot 7$ & 10 & +4.0 & $-6 \cdot 3$ & $+0 \cdot 38$ & $-11 \cdot 0$ \\
\hline $\mathrm{pRPl}$ & $44 \cdot 5$ & 11 & $+4 \cdot 3$ & $-5 \cdot 1$ & +0.56 & $-6 \cdot 3$ \\
\hline $\mathrm{R} 1 d r d 19$ & $61 \cdot 8$ & 11 & -8.6 & $-12 \cdot 1$ & -1.9 & $-14 \cdot 3$ \\
\hline $\mathrm{pWW} 0$ & 74.9 & 9 & $+6 \cdot 2$ & $+8 \cdot 2$ & +0.2 & $-9 \cdot 1$ \\
\hline RIP64 & 78 & 7 & $+14 \cdot 1$ & $+21 \cdot 9$ & $+2 \cdot 8$ & +8.6 \\
\hline CAM & 91.6 & 4 & $-35 \cdot 6$ & $+71 \cdot 5$ & $+5 \cdot 5$ & $+52 \cdot 1$ \\
\hline TP116 & $143 \cdot 6$ & 3 & -15.6 & $+5 \cdot 3$ & -0.57 & +3.0 \\
\hline pMGl & 312 & 5 & $-45 \cdot 5$ & -14.9 & $-5 \cdot 6$ & $-8 \cdot 4$ \\
\hline \multicolumn{3}{|c|}{$\begin{array}{l}\text { Mean } \$ \text { percentage error } \\
\pm 95 \% \text { confidence interval }\end{array}$} & $12 \cdot 2 \pm 5 \cdot 6$ & $12 \cdot 6 \pm 8 \cdot 0$ & $3 \cdot 0 \pm 1 \cdot 5$ & $33 \cdot 7 \pm 14 \cdot 4$ \\
\hline \multirow{2}{*}{\multicolumn{3}{|c|}{$\begin{array}{l}\text { Meant } R^{2}(\%) \\
\text { Mean† Durbin-Watson statistic }\end{array}$}} & 97.5 & $97 \cdot 1$ & $98 \cdot 6$ & $96 \cdot 0$ \\
\hline & & & 1.73 & $1 \cdot 41$ & 1.97 & 1.71 \\
\hline
\end{tabular}

Table 2. Comparison of four regression methods for calculating mean errors of predicted molecular sizes of EcoRI restriction fragments of bacteriophage $\lambda$ DNA

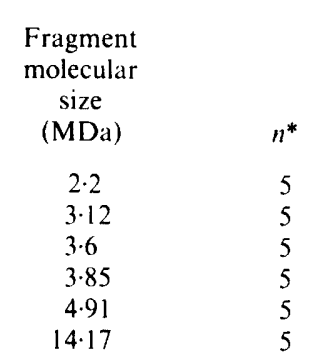

Mean $\S$ percentage error

$\pm 95 \%$ confidence interval

Meant $R^{2}(\%)$

Mean† Durbin Watson statistic
Mean† error $(\%)$ from $n$ values of predicted molecular sizes obtained with the following regressional methods: $\ddagger$

\begin{tabular}{cccc}
\hline LL & LR & MR & S \\
+2.18 & +9.82 & +0.73 & +0.18 \\
-1.32 & -0.69 & -1.05 & -1.59 \\
-0.39 & -1.89 & -0.11 & +0.15 \\
-0.42 & -2.57 & -0.03 & +0.18 \\
-0.02 & -3.59 & +0.60 & +0.85 \\
+0.22 & +1.37 & -0.04 & -0.06 \\
& & & $0.50 \pm 0.64$ \\
$0.76 \pm 0.97$ & $3.32 \pm 3.51$ & $0.43 \pm 0.45$ & 100.0 \\
99.9 & 98.4 & 99.9 & 2.42 \\
2.08 & 1.31 & 2.46 & \\
$*+\ddagger \$$ See Table 1. & &
\end{tabular}

Southern's method (Southern, 1979), which was designed for determining the size of restriction fragments, was used on our data (S). The results (Table 1) show from the high $R^{2}$ and Durbin-Watson statistics that the method gave a good linear fit. However, the errors in the predicted molecular sizes were very large and the mean percentage error for all the plasmids was 
Table 3. Comparison of three regression methods for calculating mean errors of predicted molecular sizes of plasmids obtained from a $1.4 \%$ agarose gel

$\begin{array}{lr}\text { Plasmid } & \begin{array}{r}\text { Molecular } \\ \text { size } \\ (\mathrm{MDa})\end{array} \\ \text { pVA517H } & 1.37 \\ \text { pVA517G } & 1.76 \\ \text { pVA517F } & 2.02 \\ \text { pVA517E } & 2.67 \\ \text { pVA517D } & 3.38 \\ \text { pVA517C } & 3.64 \\ \text { pVA517B } & 4.81 \\ \text { R300B } & 5 \cdot 7 \\ \text { R91 } & 48.1 \\ \text { TP116 } & 143.7\end{array}$

Mean $\S$ percentage error $\pm 95 \%$ confidence interval Meant $R^{2}(\%)$

Meant Durbin-Watson statistic

\begin{tabular}{ccc}
$\begin{array}{c}\text { Mean† error }(\%) \text { from } n \text { values of predicted } \\
\text { molecular sizes obtained with the } \\
\text { following regression methods: }\end{array}$ \\
\hline LL & LR & MR \\
+17.9 & +30.0 & +1.3 \\
+3.6 & +7.1 & +0.30 \\
-2.5 & -1.5 & -2.2 \\
-5.3 & -8.3 & +0.68 \\
-6.1 & -9.9 & +0.55 \\
-6.4 & -10.3 & -0.30 \\
+7.3 & $+9 \cdot 1$ & -0.05 \\
$\mathrm{C}$ & $\mathrm{C}$ & $\mathrm{C}$ \\
$\mathrm{ND}$ & $\mathrm{ND}$ & $\mathrm{ND}$ \\
$\mathrm{ND}$ & $\mathrm{ND}$ & $\mathrm{ND}$ \\
& & \\
$7.0 \pm 4.4$ & $10.9 \pm 7.7$ & $0.77 \pm 0.64$ \\
93.1 & 83.9 & $99 \cdot 1$ \\
1.19 & 1.08 & 2.40
\end{tabular}

C, Ran with chromosome.

ND, Not detected because plasmid too large to enter gel at this concentration.

$* \ddagger \S$, See Table 1 .

over ten times larger and more variable than our MR method. A modification of Southern's method has also been suggested (Schaffer \& Sederoff, 1981). However, both methods are computationally complex and give no advantage over our MR approach. A comparison of the four prediction methods on bacteriophage $\lambda$ restriction fragments also showed MR to be the best method (Table 2). However, in this case, where the size range of DNA fragments was smaller, the LL and Southern regressions were also much better.

The LL, LR and MR methods were also compared at a higher agarose concentration (Table 3) and at two different voltages (Table 4) for a number of plasmids. In each case MR was the best method, showing the highest $R^{2}$ values and Durbin-Watson statistics, but the lowest percentage errors and variabilities. These results suggest that the MR approach will work well under a wide range of electrophoresis conditions.

The degree of supercoiling is known to affect plasmid mobility (Wang, 1980) so the mobilities of pGSS15 and RP4 were tested using six different bacteria as plasmid hosts (three strains of $E$. coli and Pseudomonas aeruginosa, Pseudomonas putida and Acinetobacter calcoaceticus). There was no difference in the mobilities of the plasmids from the different bacteria. Thus MR can be used to accurately estimate the sizes of plasmids isolated from different bacteria because supercoiling appears to be constant in a range of bacteria. However, there is a suggestion that incubation temperature can affect supercoiling (Goldstein \& Drlica, 1984). Therefore it would be prudent to use a constant temperature to grow all the hosts in a plasmid sizing experiment.

It would be easier to estimate the size of unknown plasmids on a routine basis if a small number of organisms could supply enough plasmid standards of sufficient size range to calculate a useful regression equation. We tested this possibility by using the pVA517 range of plasmids and TP116 to estimate the sizes of RP4, pRP1, pWW0 and RIP64 which varied in size between 36.7 MDa and $78 \mathrm{MDa}$. The mean percentage error and $95 \%$ confidence limits of the estimated molecular sizes of these five plasmids $(3.63 \pm 1 \cdot 16 \%)$ was similar to that observed for MR in Table 1.

Our results indicate that plasmid sizes can be satisfactorily determined over the entire range we have used from gel electrophoresis of the eight plasmids in E. coli V517 and the single larger plasmid, TP116 in E. coli IR713. Thus the use of multiple regression with these two bacteria provides a simple and rapid method for determining the size of bacterial plasmids and other 
Table 4. Comparison of three regression methods for calculating mean errors of predicted molecular sizes of plasmids from electrophoresis gels at two different voltages

Mean† error $(\%)$ from $n$ values of predicted molecular sizes obtained from gels run at the following voltages:

\begin{tabular}{|c|c|c|c|c|c|c|c|c|}
\hline \multirow[b]{2}{*}{ Plasmid } & \multirow{2}{*}{$\begin{array}{l}\text { Molecular } \\
\text { size } \\
\text { (MDa) }\end{array}$} & \multirow[b]{2}{*}{$n^{*}$} & \multicolumn{3}{|c|}{$8 \mathrm{~V} \mathrm{~cm}^{-1}$} & \multicolumn{3}{|c|}{$22 \mathrm{~V} \mathrm{~cm}^{-1}$} \\
\hline & & & LL & LR & MR & LL & LR & MR \\
\hline pVA5I7H & 1.37 & 3 & $-9 \cdot 1$ & $+24 \cdot 7$ & $+9 \cdot 2$ & $-13 \cdot 7$ & $+20 \cdot 6$ & +0.69 \\
\hline pVA517G & 1.76 & 3 & $-6 \cdot 2$ & +8.9 & +1.8 & -5.6 & +8.9 & +0.35 \\
\hline pVA517F & 2.02 & 3 & $-8 \cdot 6$ & $+1 \cdot 3$ & $-3 \cdot 4$ & -6.9 & $+2 \cdot 3$ & $-3 \cdot 2$ \\
\hline pVA517E & $2 \cdot 57$ & 3 & $-3 \cdot 4$ & $-3 \cdot 3$ & $-2 \cdot 6$ & $-5 \cdot 5$ & $-4 \cdot 4$ & $-5 \cdot 2$ \\
\hline pVA517D & $3 \cdot 38$ & 3 & -1.9 & $-5 \cdot 5$ & $-2 \cdot 6$ & +1.5 & $-3 \cdot 2$ & -0.71 \\
\hline pVA517C & 3.64 & 3 & +1.8 & $-5 \cdot 2$ & $-2 \cdot 7$ & +2.9 & -2.9 & +0.18 \\
\hline pVA517B & 4.81 & 3 & +6.9 & $-2 \cdot 7$ & +1.4 & +7.6 & $-2 \cdot 2$ & $+3 \cdot 6$ \\
\hline R300B & $5 \cdot 52$ & 3 & +10.5 & $-0 \cdot 14$ & +4.4 & +10.7 & +0.91 & $+4 \cdot 4$ \\
\hline pVA517A & 35.8 & 3 & $+2 \cdot 8$ & -0.76 & +0.65 & +2.4 & $-1 \cdot 3$ & +0.90 \\
\hline R91 & $48 \cdot 1$ & 2 & $-0 \cdot 31$ & -2.52 & -0.39 & $-3 \cdot 5$ & -6.6 & $-4 \cdot 7$ \\
\hline TP116 & 143.6 & 2 & $-3 \cdot 4$ & +2.54 & +0.13 & -1.6 & $+4 \cdot 4$ & $-1 \cdot 3$ \\
\hline \multicolumn{3}{|c|}{$\begin{array}{l}\text { Mean§ percentage error } \\
+95 \% \text { confidence interval }\end{array}$} & $5 \cdot 0 \pm 2 \cdot 2$ & $5 \cdot 2 \pm 4 \cdot 4$ & $2 \cdot 6 \pm 1.6$ & $5 \cdot 6 \pm 2 \cdot 5$ & $5 \cdot 3 \pm 3 \cdot 6$ & $2 \cdot 3 \pm 1 \cdot 2$ \\
\hline \multirow{2}{*}{\multicolumn{3}{|c|}{$\begin{array}{l}\text { Mean } \dagger R^{2}(\%) \\
\text { Mean } \dagger \text { Durbin-Watson } \\
\text { statistic }\end{array}$}} & $99 \cdot 4$ & $99 \cdot 6$ & 99.8 & $99 \cdot 3$ & 99.1 & 99.6 \\
\hline & & & $0-63$ & 0.97 & 1.23 & $0-78$ & 1.63 & $2 \cdot 01$ \\
\hline
\end{tabular}

covalently closed circular DNA. This represents a considerable improvement over existing electrophoretic methods and has similar precision to other methods of accurate plasmid size determination such as electron microscopy contour lengths.

This work was supported by a Natural Environment Research Council grant and research studentship (M. J. B.) for which we are grateful. We also thank the following people for providing us with bacteria: P. Barth, P. Gowland, G. Jacoby, E. Juni, W. Keevil and P. Williams.

\section{REFER ENCES}

AAIJ, C. \& Borst, P. (1972). The gel electrophoresis of DNA. Biochimica et biophysica acta 269, 192-200.

Barth, P. T., Tobin, L. \& Sharpe, G. S. (1981). Development of broad host range plasmid vectors. In Molecular Biology, Pathogenicity, and Ecology of Bacterial Plasmids, pp. 439-448. Edited by S. B. Levy, R. C. Clowes \& E. L. Koenig. New York: Plenum Press.

Burton, N. F., Day, M. J. \& Bull, A. T. (1982). Distribution of bacterial plasmids in clean and polluted sites in a South Wales river. Applied and Environmental Microbiology 44, 1026-1029.

Chatterjee, S. \& Price, B. (1977). Regression Analysis by Example. New York: John Wiley.

Currier, T. C. \& Morgan, M. K. (1981). Restriction endonuclease analyses of the incompatibility group P-1 plasmids RK2, RP1, RP4, R68, and R68.45. Current Microbiology 5, 323-327.

Goldstein, E. \& DrlicA, K. (1984). Regulation of bacterial DNA supercoiling: plasmid linking numbers vary with growth temperature. Proceedings of the National Academy of Sciences of the United States of America 81, 4046-4050.
Grindley, N. D. F., Humphreys, G. O. \& Anderson, E. S. (1973). Molecular studies of R factor compatibility groups. Journal of Bacteriology 115, 387-399.

Grinter, N. J. \& Barth, P. T. (1976). Characterisation of $\mathrm{SmSu}$ plasmids by restriction endonuclease cleavage and compatibility testing. Journal of Bacteriology 128, 394-400.

HANSEN, J. B. \& OlSEN, R. H. (1978). Isolation of large bacterial plasmids and characterisation of the P-2 incompatibility group plasmids pMG1 and pMG5. Jowrnal of Bacteriology 135, 227-238.

JaCOB, A. E., Shapiro, J. A., Yamamoto, L., Smith, D. I., Cohen, S. N. \& BERG, D. (1977). Plasmids studied in Escherichia coli and other enteric bacteria. In DNA Insertion Elements, Plasmids and Episomes, pp. 607-704. Edited by A. I. Bukhari, J. A. Shapiro \& S. L. Adhya. Cold Spring Harbor, New York: Cold Spring Harbor Laboratory.

JaCoby, G. A., Sutton, L., Knobel, L. \& Mammen, P. (1983). Properties of IncP-2 plasmids of Pseudomonas spp. Antimicrobial Agents and Chemotherapy 24, 168-175.

KaDO, C. I. \& LIU, S. T. (1981). Rapid procedure for 
detection and isolation of large and small plasmids. Journal of Bacteriology 145, 1365-1373.

Korfhagen, T. R., Sutton, L. \& Jacoby, G. A (1978). Classification and physical properties of Pseudomonas plasmids. In Microbiology, pp. 221224. Edited by D. Schlessinger. Washington: American Society for Microbiology.

LANKA, E. \& BarTh, P. T. (1981). Plasmid RP4 specifies a DNA primase involved in its conjugal transfer and maintenance. Journal of Bacteriology 148, 769-781.

Lehrbach, P. R., McGregor, I., Ward, J. M. \& Broda, P. (1983). Molecular relationships between Pseudomonas IncP-9 degradative plasmids TOL, NAH, and SAL. Plasmid 10, 164-174.

Macrina, F. L., Kopecko, D. J., Jones, K. R., Ayers, D. J. \& MCCOWEN, S. M. (1978). A multiple plasmid containing Escherichia coli strain: a convenient source of size reference molecules. Plasmid 1, 417 420.

Meyers, J. A., Sanchez, D., Elwell, L. P. \& Falkow, S. (1976). Simple agarose gel electrophor- etic method for the identification and characterisation of plasmid deoxyribonucleic acid. Journal of Bacteriology 127, 1529-1537.

Ryan, T. A., JoInter, B. L. \& Ryan, B. F. (1976). Minitab Student Handbook. North Scituate, USA: Duxbury Press.

SCHAFFER, H. E. \& SEderofF, R. R. (1981). Improved estimation of DNA fragment lengths from agarose gels. Analytical Biochemistry 115, 113-122.

SOUTHERN, E. M. (1979). Measurement of DNA length by gel electrophoresis. Analytical Biochemistry 100, 319-323.

Velleman, P. F. \& Hoaglin, D. C. (1981). Applications, Basics, and Computing of Exploratory Data Analysis. Boston, USA : Duxbury Press.

WANG, J. C. (1980). Superhelical DNA. Trends in Biochemical Sciences 5, 219-221.

Willshaw, G. A., Smith, H. R. \& Anderson, E. S. (1979). Application of agarose gel electrophoresis to the characterization of plasmid DNA in drugresistant enterobacteria. Journal of General Microbiology 114, 15-25. 